\title{
Types of E-Procurement Systems and Technologies Used in the Nigerian Construction Environment
}

\author{
Egidario B. Aduwo, Eziyi O. Ibem, Adedamola A. Oluwnmi, Afolabi O. Adedeji
}

\begin{abstract}
The use of e-Procurement in the acquisition of construction works and services has witnessed a tremendous growth in the past three decades across the world. However, in a developing country like Nigeria, there is the lack of understanding of the different types of e-Procurement systems and specific technologies used to support the execution of construction procurement tasks. This study, therefore, relied on a questionnaire survey of 759 users of e-Procurement to systematically identify the different types of e-Procurement systems and technologies used in the Nigerian construction environment. The results of data analysis revealed that whereas the common e-Procurement systems used in the study area are those that help in disseminating/receiving information on tender opportunities, exchanging construction project information/data, submitting tenders, awarding contracts, placing orders and making/receiving payment for materials/equipment and services, the use of systems that help in tracking the movement of materials/equipment and monitoring the progress of work on construction sites was not very common. In addition, it was also found that the main e-Procurement technologies used to support the execution of construction procurement activities in the study area were e-Mails, websites and web portals. The study concludes that the over reliance on simple e-Procurement technologies such as $\mathrm{e}$-Mail and websites/portals with limited capacity to engender collaboration, integration and coordination of tasks is inconsistent with the growing sophistication and advancement in construction procurement activities and processes and that this has a tendency to limit the benefits associated with e-Procurement in construction project delivery in Nigeria.
\end{abstract}

Keywords: Construction project, e-Procurement, Nigeria, Systems and Technologies.

\section{INTRODUCTION}

The Nigerian construction environment is witnessing a significant change as a result of globalization and advancement in technology. Specifically, the advent of the Internet and increasing changes in human needs,

Revised Manuscript Received on April 18, 2020.

* Correspondence Author

Egidario B. Aduwo*, Department of Architecture, Covenant University, Ota, Nigeria. Email: egidario.aduwo@covenantuniversity.edu.ng

Eziyi O. Ibem, Department of Architecture, University of Nigeria, Enugu Campus, Enugu, Nigeria. Email: eziyi.ibem@unn.edu.ng

Adedamola A. Oluwunmi, Department of Estate Management, Covenant University, Ota, Nigeria, Email: funke.oluwunmi@covenantuniversity.edu.ng

Afolabi O. Adedeji, Department of Building Technology, Covenant University, Ota, Nigeria. adedeji.afolabi@covenantuniversity.edu.ng.

(c) The Authors. Published by Blue Eyes Intelligence Engineering and Sciences Publication (BEIESP). This is an open access article under the CC BY-NC-ND license (http://creativecommons.org/licenses/by-nc-nd/4.0/) aspirations and expectations have compelled professionals and other stakeholders in the industry globally and locally to rethink the way construction businesses are carried out.Previous studies [1-2] have indicated that the emergence of new level of complexity in the industry, communication, different relationships, partnering, markets and global business standards and rules have made it necessary for the construction industry to leverage the prevailing digital climate to improve the fortunes of the sector in meeting the needs and expectations of its clientele in the delivery of buildings and infrastructure projects in a sustainable manner. This has become very important, especially at this time when there is a need to ensure that clients get value for money in the procurement of buildings and other fixed infrastructure.

It has been observed that the Internet has become a major catalyst for change in most industrial sectors, including construction [3], hence previous authors have argued that the use of Internet-based technologies, applications, and processes has the capabilities to improve administrative performance, especially in the procurement of goods and services [4]. In line with this, electronic (e-) Procurement, which is the use of the Internet to acquire works, goods and services $[2,5,6]$ has been recognized as a powerful tool for enhancing productivity and transparency in all forms of procurement activities [7-8]. Research on e-Procurement in construction has been on the increase since the mid-1990s. The existing studies have examined several issues such as the level of adoption of e-Procurement [2, 9-12], the associated benefits [13-15], situations that militate against its successful adoption [2,13-15] and the critical success factors for its adoption in construction business [16]. In Nigeria, previous a study examined the current state of e-Tendering in the construction sector [17]. Although that study made attempt at identifying some e-Tendering tools used in the Nigerian construction industry, the findings are applicable only to e-Tendering systems. Other authors $[12,18]$ had investigated the extent of adoption of e-Procurement and factors that influenced its use in the procurement of building projects in this country, respectively. However, the findings of these two studies cannot be generalised in the context of the Nigerian construction environment because of their narrow focus on the building sector, which is a sub-set of the construction industry. 
A more recent study was on the critical success factors for the adoption of e-Procurement but it failed to consider the specific types e-Procurement systems and technologies used by stakeholders in the procurement of construction works, goods and services in this country [16]. The foregoing suggests that although there is a growing body of scientific knowledge on e-Procurement in construction, there is still a knowledge gap in the area of the specific types of e-Procurement systems and technologies currently in use in the Nigerian construction environment. This has obscured our understanding of the types of e-Procurement systems available and presently deployed in the procurement of construction projects in Nigeria, the largest economy in Africa. In view of this, this study investigated the e-Procurement systems, tools and technologies used by stakeholders in the Nigerian construction industry. The research pursued two basic objectives, which are: (i) to identify the types of e-Procurement systems used in the Nigerian construction industry and (ii) to examine the different e-Procurement technologies used to support the execution of construction procurement activities in the study area. The research is based on a survey of 759 users of e-Procurement in the Nigerian construction industry. This research investigated the following e-Procurement systems: e-Notification, e-Tendering/Submission, e-Exchange, e-Awarding systems, e-Tracking and e-Payment systems. The study makes contribution to knowledge by improving understanding of the different types of e-Procurement systems and technologies existing in Nigeria and level of their deployment in the country's construction environment. Therefore, the findings of this research are expected to inform intending users as well developers and vendors of e-Procurement systems within and outside Nigeria on the availability and deployment of the different types of e-Procurement systems and technologies in this country's construction environment.

\section{LITERATURE REVIEW}

The review of literature is divided into two sections. The first section covers the review of literature on the different types of e-Procurement systems, while the second is on the various e-Procurement tools and applications that can be used to support the execution of construction procurement activities.

\section{A. Types of e-Procurement Systems}

As used in this research e-Procurement refers to the use of web-based methods and tools in forming contracts, obtaining prices, awarding and managing construction-related contracts [19]. In its simplest form, it is using e-Ecommerce systems and processes to procure construction- related works, goods and services. Generally speaking, e- Commerce transactions can be classified into three basic categories based on their functions. The first category includes transactions involving product information marketing. The second category deals with acquisition of goods and services, while the last category involves exchange of contract documents and electronic payment [20]. These transactions are usually carried out using different online platforms, which are referred to as e-Procurement systems [21].
Table I presents a summary of the existing e-Procurement systems as gleaned from the literature. Examination of the description of these systems reveals that each of them provides the platform for executing at least one procurement activity, while a combination of them can enable the exchange of complete information required to carry out substantial aspect of procurement activities. Although, the use of these e-Procurement systems may vary from one industry to another and from firm to firm, the primary role of the different systems is to facilitate uninterrupted and timely exchange of information and/or data among the various stakeholders involved in construction procurement activities and processes. The review of the existing literature also reveals that the identified e-Procurement systems have their origins and might have different names depending on the industry of application, especially in the retail and manufacturing sectors that are regarded as early adopters of e-Procurement [21]. Notably, some of these systems have found usefulness in the procurement of construction works, materials/equipment and services as previous authors have observed $[2,19]$. It is also important to note that there are several tools, applications and packages associated with each of these systems. This is why it is important to investigate the ones associated with each and map them against the different construction procurement activities each can be used to execute to assist intending users make quick decision on the ones to use at any stage of the procurement process.

Table 1: Types of e-Procurement systems

\begin{tabular}{|l|l|}
\hline $\begin{array}{l}\text { e-Procuremen } \\
\text { t System }\end{array}$ & \multicolumn{1}{|c|}{ Description } \\
\hline $\begin{array}{l}\text { Web-based } \\
\text { Enterprise } \\
\text { Resource } \\
\text { Planning (ERP) }\end{array}$ & $\begin{array}{l}\text { The use of Internet-based software system to } \\
\text { create and approve purchasing requisitions, } \\
\text { place purchase orders and receive goods and } \\
\text { services. }\end{array}$ \\
\hline $\begin{array}{l}\text { Electronic } \\
\text { Maintenance, } \\
\text { Repair } \\
\text { Overhaul } \\
\text { (e-MRO) }\end{array}$ & $\begin{array}{l}\text { Similar to ERP, but goods and service } \\
\text { procured are not for productive activities, but } \\
\text { are mostly indirect goods }\end{array}$ \\
\hline $\begin{array}{l}\text { Electronic data } \\
\text { interchange } \\
\text { (EDI) }\end{array}$ & $\begin{array}{l}\text { Inter-organizational information system } \\
\text { using structured exchange protocols usually } \\
\text { through value added networks. Used mostly } \\
\text { to exchange messages concerning such } \\
\text { matters related to orders, confirmations, } \\
\text { transportation information and invoicing. }\end{array}$ \\
\hline $\begin{array}{l}\text { e-Reverse } \\
\text { auctioning }\end{array}$ & $\begin{array}{l}\text { Using Internet technologies to bid down } \\
\text { bidders price offer against those of other } \\
\text { bidders until no further downward bids are } \\
\text { received. } \\
\text { seceive tenders for the supply of goods and } \\
\text { services. }\end{array}$ \\
\hline e-Sourcing & $\begin{array}{l}\text { Using Internet technology to identify new } \\
\text { needed by an organization. }\end{array}$ \\
\hline
\end{tabular}




\begin{tabular}{|l|l|} 
e-Informing & $\begin{array}{l}\text { Gathering and circulating procurement } \\
\text { information to both internal and external } \\
\text { parties on the Internet }\end{array}$ \\
\hline e-Awarding & $\begin{array}{l}\text { Opening of tenders, evaluation of tenders, } \\
\text { tender selection and tender award using } \\
\text { Internet facilities. }\end{array}$ \\
\hline e-Collaboration & $\begin{array}{l}\text { Collaborative procurement related planning } \\
\text { and design using facilitating technologies. }\end{array}$ \\
\hline e-Ordering & $\begin{array}{l}\text { The use of Internet to facilitate operational } \\
\text { purchasing process, including requisition, } \\
\text { order approval, order receipt and payment } \\
\text { process. }\end{array}$ \\
\hline e-Markets & $\begin{array}{l}\text { Meeting venues for components suppliers } \\
\text { and purchasers, who exchange mechanism to } \\
\text { support procurement process electronically. } \\
\text { E-catalogues play key role in e-Market } \\
\text { places. }\end{array}$ \\
\hline e-Contracting \\
Management
\end{tabular}

Source: Compiled by the authors from [21-23]

\section{B. e-Procurement Technologies and their Applications in Construction Procurement}

Procurement activities are usually conducted using a number of communication media, which facilitate the exchange of information among the various parties. These communication media are driven by specific technologies in the forms of tools, applications or processes. Generally speaking, e-Procurement technologies are applications, tools or processes designed to facilitate the acquisition of goods and services by a commercial or government organization over the Internet [24]. Examples of e-Procurement technologies include e-mails, websites, web portals, Intranet, Extranet, Videoconference, Electronic Data Interchange (EDI), Radio Frequency Identification (RFID), Mobile wireless Technology, Customized e-procurement software, e-Markets, web-based building information modelling (BIM) and others [24-25]. The basic requirements for establishing e-Procurement technologies are computer hard ware, software and network system, and these e-Procurement technologies can only be deployed to support the execution of procurement activities related to information gathering and information exchange among parties, contracting, requisition and intelligence and analysis. This suggests that the logistic aspect such as the delivery or assemblage of physical products is beyond the capabilities of e-Procurement systems and technologies [25].

Regarding the use of e-Procurement technologies to support the execution of construction procurement activities, in a study of contractors in the USA, it was reported that despite the fact that construction is mainly a service oriented industry, a majority of its activities require material handling and assembly [26]. As a result, e-Procurement is considered one of the commonly adopted e-Business practices critical to the success of construction business, especially as construction works involves a number of participants in each project who have the need for inventory management. That study reported massive use of e-Mails and fax, project management software applications, Extranet/Intranet and electronic data interchange (EDI) to support the exchange of construction project information and data [26]. In Australia, other authors also reported 100 percent, 37 percent and 30 percent use of e-Mail, Intranet and Extranet, respectively, to carry out online searching and ordering of construction materials/equipment; exchange of construction drawings; project management and send or receive tender offers [27]. Further, another study investigated e-Procurement adoption amongst 226 general and trade contractors, suppliers and their associates in the Atlantic Canadian construction industry and reported that the e-Procurement technologies such as e-Mails and websites used for searching and finding production information, responding to bidding opportunities and transferring bidding information and documents online offered a number of advantages in greater access to market, reducing paperwork, increasing productivity and reducing procurement cycle time[20].

Elsewhere in South Africa, e-Mail, static websites, web 2.0 technologies, and portals were reported to have been used by stakeholders in that country's construction industry in sending or receiving information on tender opportunities, while e-Mails, Web 2.0-based systems; websites, and cloud-based applications were used to support the exchange of construction project information [2]. In Nigeria, it was reported that e-Procurement technologies have been used at the different stage of construction procurement process to carry out the following activities: preparation of tenders, production of contract drawings, tender analysis, contract formulation, tendering, distribution of contract drawings, interaction with professionals, obtaining design brief from clients and consultation with clients [17]. Others are submission of tenders, receipt of tender notification, receipt of payment and making payment for construction related works and services [17]. In a similar study in the Nigerian building industry, it was found stakeholders used e-Procurement technologies such as e-Mail to announce or receive information on call for tenders/ request for quotations and exchange project briefs/specifications and in the submission/receipt of tenders/ proposals/expression of interest as well as static websites and e-Catalogues and electronic fund transfer (EFT) to identify and place orders for construction materials and equipment as well as make payments for building procurement-related services, respectively[12].

From the forgoing review, it is evident that previous studies have examined the different e-Procurement technologies used to support the execution of some construction procurement activities. Consequently, there is a growing knowledge of the existing systems and technologies available for use in the different industries. Since these studies cannot be said to be conclusive as research

Published By:

Blue Eyes Intelligence Engineering

\& Sciences Publication

(C) CoDvriaht: All riahts reserved.

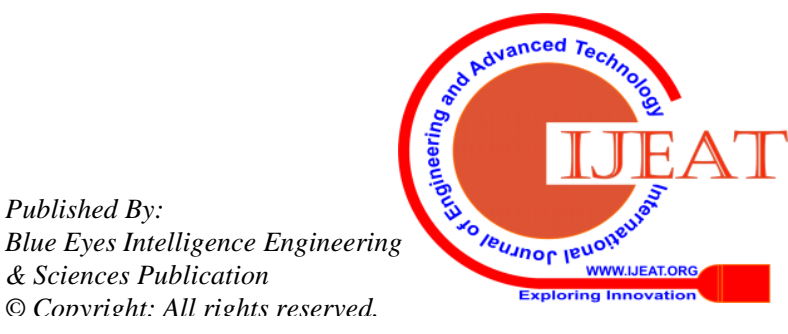


efforts are underway to develop new ones that would enhance efficiency in service delivery, more research works are needed in this areas, particularly in a developing country like Nigeria, where very few studies on the various types of e-Procurements systems and extent of their use exist.

\section{RESEARCH METHODS}

This paper draws on a bigger research project designed to investigate e-Procurement use in the Nigerian construction industry. The target population consist of consulting and contracting firms, private and public sectors clients' organizations and building materials suppliers/vendors. Participants in the survey were selected from the six geopolitical zones in Nigeria: Northcentral, Northeast, Northwest, Southeast, South-south, and Southeast. The research design adopted was across-sectional survey because of its advantage in allowing the collection of huge volume of data from a widely dispersed population within a relatively short time. Moreover, previous authors [12,26-27] had adopted this approach. The sample size for the research was estimated using the formula for infinite population given in equation 1:

$$
\text { Minimum Sample size, } \mathrm{n}_{0}=\frac{Z^{2} p q}{e^{2}} \quad \ldots . . \text { Equation }
$$

$1[28]$

Where $\mathrm{n}_{0}$ is the minimum sample size, $\mathrm{Z}$ is the critical value for $95 \%$ level of confidence, which in this case is $1.96 ; p=0.5$; $\mathrm{q}=1-p$ and $\boldsymbol{e}$ is the desired level of precision in the estimate. Using this formula, the minimum sample size obtained was 385 participants. Notably, this formula was adopted in estimating the sample size for the survey because the population of construction industry stakeholders in Nigeria is huge and the actual number of users of e-Procurement technologies and systems in the Nigerian construction environment is not known.

The data gathering instrument used was a questionnaire designed by the authors. Although the questionnaire used in the larger survey was divided into five segments, the data presented in the paper were derived from the first two segments of the instrument. Precisely, the first segment was used to gather data on the personal profiles of the participants and their respective firms/organizations they were affiliated to at the time the survey took place. The second part of the questionnaire was used to identify the different e-Procurement systems and technologies used by the participants' organizations. On the one hand, the e-Procurement systems investigated are e-Notification/Informing/Announcement, e-Exchange, e-Tendering e- Tracking and e-Payment systems. On the other hand, the key e-Procurement technologies investigated are e-mail, drobox, building information modeling (BIM), e-Markets, electronic data exchange (EDI), geographic information system (GIS), radio-frequency identification (RFID); project management software packages and e-Tendering systems.

In order to identify the actual users of e-Procurement systems and technologies in the Nigerian construction environment, the participants were firstly asked to indicate whether or not their firms/organizations had participated in construction project(s) that involved the deployment of e-Procurement systems and technologies using Yes or No options. They were secondly asked to indicate whether or not they have used any of the listed e-Procurement systems using Yes or No options. To identify the specific e-Procurement technologies (technologies, tools or applications) used under each of the systems identified, the participants were thereafter asked to select from among the list of e-Procurement technologies previously listed. Prior to the main survey, the questionnaire was pre-tested in selected architectural, building construction and quantity surveying firms in Lagos southwest Nigeria. The feedback from this exercise was used to adjust some of the questions in the final version of the instrument. The actual survey which took place between November 2017 and August 2018 in Nigeria involved the distribution of 1750 hard copies of the questionnaire to randomly selected participants in main urban centers in Nigeria: Kaduna (Northwest), Abuja (Northcentral), Lagos and Ibadan (Southwest), Port-Harcourt and Uyo (South-south) and Owerri and Enugu (Southeast). However, because of the security challenges in the Northeast zone of the country and the inability of the researchers and the recruited field assistants to visit all the urban centers in the study area, additional 250 copies of the questionnaire were sent to participants via e-Mail. The random sampling technique was used in the selection of participants to ensure that every member in the research population had equal chances of being included in the survey.

Totally, 2000 copies of the questionnaire were distributed among construction industry stakeholders in Nigeria. However, 1100 were retrieved, of which 1092 copies of the questionnaire representing around $55 \%$ of the total number of administered manually and electronically were correctly filled. Of this number, 759 copies of the questionnaire presenting about $69.5 \%$ of the total number of questionnaires retrieved were filled by actual users of e-Procurement systems and technologies in the study area. As a result, only data collected from this sub-set of the research population were analysed and the results presented in this paper. Based on the nature of the research objectives, the data were analysed using descriptive statistics with frequency distributions, percentages and cross-tabulation being the main types of descriptive statistics used. The results are presented using tables and charts.

\section{RESULT AND DICUSSION}

\section{A. Background information of the Participants and their Organizations}

Table 2 shows the background information of participants in the survey and their respective organizations. The results (Table 2) reveal that participants in the survey included Quantity surveyors (26.4\%), Architects (25.2\%) and Engineers (15.8\%), Builders (9.1\%) and contractors (6. 9\%).Table 2 also indicates that most of the participants were employed in consulting and contracting firms with construction procurement experience in building design, and construction and have been using e-Procurement systems and technologies for between 1 year and 10 years. 
This result is well expected because Quantity surveyors, Architects, Engineers and Builders are among the key professionals in the Nigerian construction environment involved in the design and construction of buildings either as professional consultants or as contractors. They constitute the bulk of participants in the Nigeria construction arena. Indeed, these results show that the participants in the research are the key stakeholders in the Nigerian construction industry and are well qualified to provide reliable data for the research.

Table 2: Participants' Role in the Industry and Profiles of their Organizations

\begin{tabular}{|c|c|}
\hline Categories & $\begin{array}{l}\text { Frequency } \\
\qquad n=759 f(\%)\end{array}$ \\
\hline \multicolumn{2}{|l|}{ Role in the construction industry } \\
\hline Architect & $191(25.2)$ \\
\hline Builder & $69(9.1)$ \\
\hline Engineer & $120(15.8)$ \\
\hline Contractor & $52(6.9)$ \\
\hline Construction/Project Manager & $37(4.9)$ \\
\hline Quantity Surveyor & $200(26.4)$ \\
\hline Estate/ Facilities Manager & $55(7.2)$ \\
\hline $\begin{array}{l}\text { Supply Chain Manager/ Procurement } \\
\text { Officer }\end{array}$ & $30(3.9)$ \\
\hline $\begin{array}{l}\text { Construction Materials/Equipment } \\
\text { Vendors }\end{array}$ & $5(0.6)$ \\
\hline \multicolumn{2}{|l|}{ Type of organization } \\
\hline Consulting firm & 242(31.9) \\
\hline Contracting firm & $265(34.9)$ \\
\hline Private sector client organization & $58(7.6)$ \\
\hline $\begin{array}{l}\text { Government Ministry/Parasatal/ } \\
\text { Institution }\end{array}$ & $171(22.5)$ \\
\hline $\begin{array}{l}\text { Building Materials } \\
\text { Manufacturer/Vendors }\end{array}$ & $3(0.4)$ \\
\hline Others & $20(2.6)$ \\
\hline \multicolumn{2}{|c|}{ Areas of construction procurement experience } \\
\hline Residential buildings & 474(62.5) \\
\hline Non-residential buildings & $187(24.6)$ \\
\hline Buildings and Transportation & $36(4.7)$ \\
\hline Energy & $16(2.1)$ \\
\hline Transportation & $26(3.4)$ \\
\hline Telecommunication & $12(1.6)$ \\
\hline Sanitation and Water Supply & $5(0.7)$ \\
\hline Others & $3(0.4)$ \\
\hline \multicolumn{2}{|c|}{ Duration of e-Procurement use in years } \\
\hline Less than 1 year & $155(20.4)$ \\
\hline Between 1 year and 5 years & $363(47.8)$ \\
\hline Between 6 and 10 years & $112(14.8)$ \\
\hline .Over 10 years & $40(5.3)$ \\
\hline Not Sure & $89(11.7)$ \\
\hline
\end{tabular}

\begin{tabular}{|l|c|}
\hline Age of Organization & $138(18.2)$ \\
\hline Below 5years & $197(26.0)$ \\
\hline 6-10years & $402(53.0)$ \\
\hline 11years+ & $22(2.9)$ \\
\hline No Response & \\
\hline
\end{tabular}

B. Types of e-Procurement systems used

Figure 1 is a display of the results on the users and non-users of different e-Procurement systems at the pre-contract stage of construction projects.

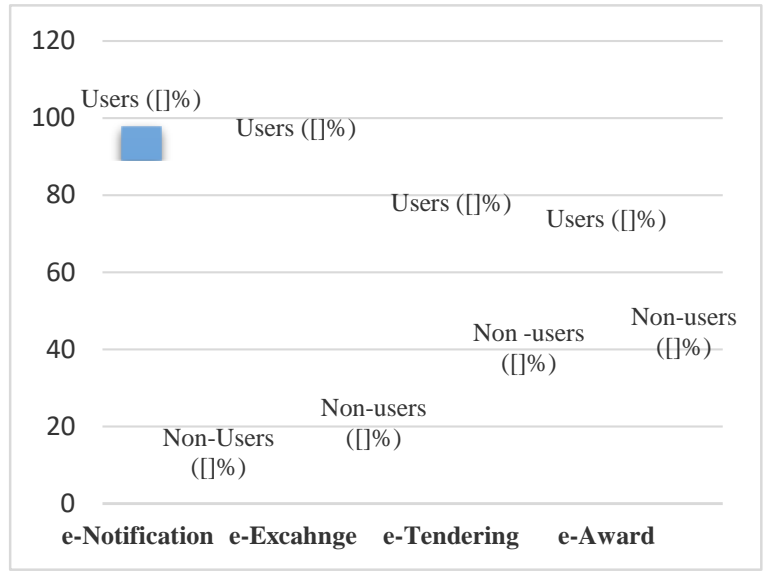

Fig.1: e-Procurements used at pre-contract stage

The results in Figure 1 reveals that a majority (98\%, 90\%, $71 \%$ and $67 \%$ ) of the organizations are users of e-Notification, e-Exchange, e-Tendering, and e-Award. These results indicate that the most used e-Procurement system in the Nigerian construction environment is e-Notification, followed by e-Exchange, e-Tendering and e-Award systems, respectively Figure 2 is also a display of the results of the users and non-users of e-Procurement systems at the post-contract award stage of construction projects. As shown in Figure 2 most of the organizations sampled (78\% and $72 \%$ ) are users of e-Payment and e-Ordering systems, respectively, while $48 \%$ are users of e-Tracking system. It was observed that all the building materials manufacturers and vendors who participated in survey are users of e-Payment system.

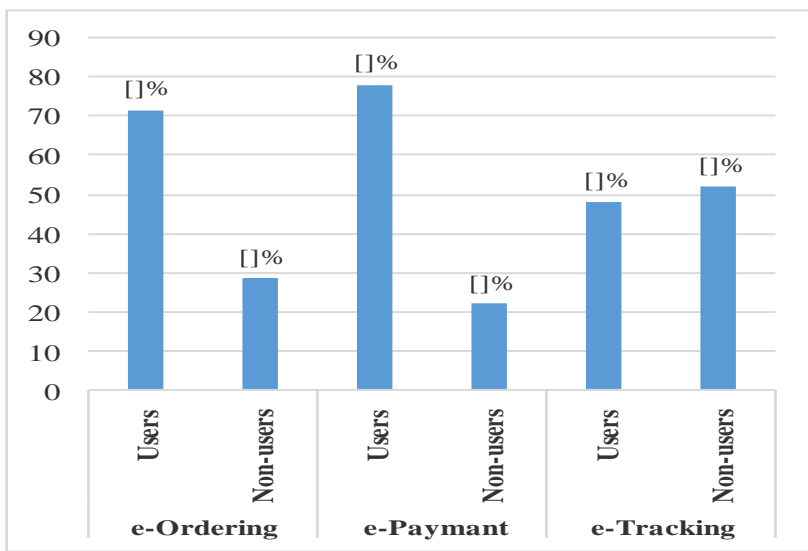

Fig.2: e-Procurement Systems used at the Post-Contract Award Stage

Published By:

Blue Eyes Intelligence Engineering

\& Sciences Publication

(C) CoDvriaht: All riahts reserved.

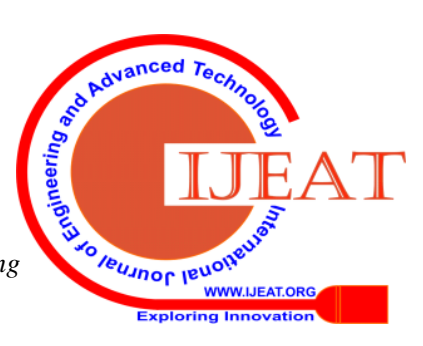




\section{C. e-Procurement Technologies used by the Participants}

The specific e-Procuremsent technologies used to support the execution of identified construction procurement activities were also investigated. Table 3 shows the technologies used to disseminate information related to award of construction contracts.

Table 3: e-Award Technologies

\begin{tabular}{|c|c|c|c|c|c|}
\hline \multirow{2}{*}{\begin{tabular}{|l|} 
Role in the \\
Construction Industry
\end{tabular}} & \multicolumn{5}{|c|}{ e-Award Technologies } \\
\hline & None & e-Mail & $\begin{array}{c}\text { Web- } \\
\text { based } \\
\text { EDI }\end{array}$ & Website & $\begin{array}{l}\text { Project } \\
\text { portal }\end{array}$ \\
\hline Architect & $\begin{array}{c}60 \\
(31.4) \\
\end{array}$ & $\begin{array}{c}112 \\
(58.6) \\
\end{array}$ & $\begin{array}{c}6 \\
(3.1) \\
\end{array}$ & $\begin{array}{c}11 \\
(5.8) \\
\end{array}$ & $\begin{array}{c}2 \\
(1.1) \\
\end{array}$ \\
\hline Builder & $\begin{array}{c}14 \\
(20.3)\end{array}$ & $\begin{array}{c}46 \\
(66.7) \\
\end{array}$ & $\begin{array}{c}4 \\
(5.8)\end{array}$ & $\begin{array}{c}4 \\
(5.8)\end{array}$ & $\begin{array}{c}1 \\
(1.5)\end{array}$ \\
\hline Engineer & $\begin{array}{c}39 \\
(32.5) \\
\end{array}$ & $\begin{array}{c}66 \\
(55.0) \\
\end{array}$ & $\begin{array}{c}2 \\
(1.7)\end{array}$ & $\begin{array}{c}9 \\
(7.5) \\
\end{array}$ & $\begin{array}{c}4 \\
(3.3) \\
\end{array}$ \\
\hline Contractor & $\begin{array}{c}15 \\
(28.9)\end{array}$ & $\begin{array}{c}30 \\
(57.7)\end{array}$ & $\begin{array}{c}1 \\
(1.9)\end{array}$ & $\begin{array}{c}3 \\
(5.8)\end{array}$ & $\begin{array}{c}3 \\
3(5.8) \\
\end{array}$ \\
\hline $\begin{array}{l}\text { Construction/ } \\
\text { Project Manager }\end{array}$ & $\begin{array}{c}9 \\
(24.3) \\
\end{array}$ & $\begin{array}{c}19 \\
(51.4) \\
\end{array}$ & $\begin{array}{c}4 \\
(10.8) \\
\end{array}$ & $\begin{array}{c}3 \\
(8.1) \\
\end{array}$ & $\begin{array}{c}2 \\
(5.4) \\
\end{array}$ \\
\hline Quantity Surveyor & $\begin{array}{c}76 \\
(38.0) \\
\end{array}$ & $\begin{array}{c}10 \\
4(52.0)\end{array}$ & $\begin{array}{c}5 \\
(2.5) \\
\end{array}$ & $\begin{array}{c}9 \\
(4.5)\end{array}$ & $\begin{array}{c}7 \\
(3.5)\end{array}$ \\
\hline $\begin{array}{l}\text { Estate/ Facilities } \\
\text { Manager }\end{array}$ & $\begin{array}{c}35 \\
(63.7) \\
\end{array}$ & $\begin{array}{c}16 \\
(29.1)\end{array}$ & $\begin{array}{c}2 \\
(3.6) \\
\end{array}$ & $\begin{array}{c}2 \\
(3.6) \\
\end{array}$ & $\begin{array}{c}0 \\
(0.0)\end{array}$ \\
\hline $\begin{array}{l}\text { Supply Chain } \\
\text { Manager/ } \\
\text { Procurement Officer }\end{array}$ & $\begin{array}{c}6 \\
(20.0)\end{array}$ & $\begin{array}{c}19 \\
(63.3)\end{array}$ & $\begin{array}{c}1 \\
(3.3)\end{array}$ & $\begin{array}{c}3 \\
(10.0)\end{array}$ & $\begin{array}{c}11 \\
(3.3)\end{array}$ \\
\hline $\begin{array}{l}\text { Construction } \\
\text { Materials/Equipment } \\
\text { Vendor } \\
\end{array}$ & 0 & $\begin{array}{c}5 \\
(100.0)\end{array}$ & 0 & 0 & 0 \\
\hline Total & $\begin{array}{c}254 \\
(33.5)\end{array}$ & $\begin{array}{c}416 \\
(54.8)\end{array}$ & $\begin{array}{c}25 \\
(3.3)\end{array}$ & $\begin{array}{c}44 \\
(5.8)\end{array}$ & $\begin{array}{c}19 \\
(2.5)\end{array}$ \\
\hline
\end{tabular}

The results on the e-Award technologies identified in the study area are displayed in Table 3. The results show that the common e-Procurement technology used to communicate information on the award of construction contract by those who participated in the survey is e-Mail, followed by websites and web-based EDI.

Table 4 are the results of e-Procurement technologies used for placing orders for construction materials/ equipment identified in the survey. It is evidence from the results that the three top leading e-Ordering technologies used by the participants in the survey are e-Mail, website and e-Market Place. However, technologies such as e-Reverse auctioning, web-supported EDI and Internet-based GIS are rarely used. The use of e-Mail as e-Ordering technology as found in this survey appears to be similar to the findings of previous studies in the USA [26] in Australia [27], and in the Atlantic Canadian construction industry [20]as previously discussed in the literature review section of this paper.

Table 4: e-Ordering technologies used

\begin{tabular}{|c|c|c|c|c|c|c|c|c|}
\hline \multirow[b]{2}{*}{$\begin{array}{l}\text { Role in the } \\
\text { Constructio } \\
\text { n Industry }\end{array}$} & \multicolumn{8}{|c|}{ e-Ordering Technologies } \\
\hline & 苂 & 兽 & 童 & 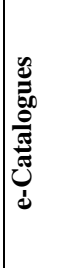 & 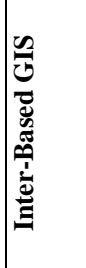 & 苞 & 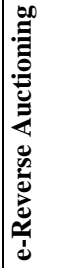 & 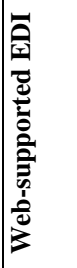 \\
\hline Architect & $\begin{array}{c}61 \\
(31.9)\end{array}$ & $\begin{array}{c}15 \\
(7.9)\end{array}$ & $\begin{array}{c}59 \\
(30.9)\end{array}$ & $\begin{array}{c}9 \\
(4.7) \\
\end{array}$ & $\begin{array}{c}2 \\
(1.1) \\
\end{array}$ & $\begin{array}{c}41 \\
(21.5)\end{array}$ & 0 & $\begin{array}{c}4 \\
(2.1) \\
\end{array}$ \\
\hline Builder & $\begin{array}{c}8 \\
(11.6)\end{array}$ & $\begin{array}{c}13 \\
(18.8)\end{array}$ & $\begin{array}{c}20 \\
(29.0)\end{array}$ & $\begin{array}{c}5 \\
(7.3)\end{array}$ & 0 & $\begin{array}{c}20 \\
(29.0)\end{array}$ & $\begin{array}{c}1 \\
(1.5)\end{array}$ & $\begin{array}{c}2 \\
(2.9)\end{array}$ \\
\hline
\end{tabular}

\begin{tabular}{|c|c|c|c|c|c|c|c|c|}
\hline Engineer & $\begin{array}{c}34 \\
(28.3)\end{array}$ & $\begin{array}{c}16 \\
(13.3)\end{array}$ & $\begin{array}{c}28 \\
(23.3)\end{array}$ & $\begin{array}{c}6 \\
(5.0)\end{array}$ & $\begin{array}{c}6 \\
(5.0)\end{array}$ & $\begin{array}{c}30 \\
(25.0)\end{array}$ & $\begin{array}{c}1 \\
(0.8)\end{array}$ & $\begin{array}{c}1 \\
(0.8)\end{array}$ \\
\hline Contractor & $\begin{array}{c}9 \\
(17.3)\end{array}$ & $\begin{array}{c}5 \\
(9.6)\end{array}$ & $\begin{array}{c}10 \\
(19.2)\end{array}$ & $\begin{array}{c}1 \\
(1.9)\end{array}$ & $\begin{array}{c}1 \\
(1.9)\end{array}$ & $\begin{array}{c}23 \\
(44.2)\end{array}$ & $\begin{array}{c}0 \\
(0.0)\end{array}$ & $\begin{array}{c}3 \\
(5.8)\end{array}$ \\
\hline $\begin{array}{l}\text { Constructi } \\
\text { on/Project } \\
\text { Manager }\end{array}$ & $\begin{array}{c}7 \\
(18.9)\end{array}$ & $\begin{array}{c}4 \\
(10.8)\end{array}$ & $\begin{array}{c}11 \\
(29.7)\end{array}$ & $\begin{array}{c}4 \\
(10 . \\
8)\end{array}$ & $\begin{array}{c}4 \\
(10.8)\end{array}$ & $\begin{array}{c}4 \\
(10.8)\end{array}$ & $\begin{array}{c}1 \\
(2.7)\end{array}$ & $\begin{array}{c}2 \\
(5.4)\end{array}$ \\
\hline $\begin{array}{l}\text { Quantity } \\
\text { Surveyor }\end{array}$ & $\begin{array}{c}67 \\
(33.5)\end{array}$ & $\begin{array}{c}20 \\
(10.0)\end{array}$ & $\begin{array}{c}16 \\
(8.0)\end{array}$ & $\begin{array}{c}11 \\
(5.5)\end{array}$ & $\begin{array}{c}5 \\
(2.5)\end{array}$ & $\begin{array}{c}79 \\
(39.5)\end{array}$ & 0 & $\begin{array}{c}2 \\
(1.0)\end{array}$ \\
\hline $\begin{array}{l}\text { Estate/ } \\
\text { Facilities } \\
\text { Manager }\end{array}$ & $\begin{array}{c}26 \\
(47.3)\end{array}$ & $\begin{array}{c}7 \\
(12.7)\end{array}$ & $\begin{array}{c}9 \\
(16.4)\end{array}$ & $\begin{array}{c}1 \\
(1.8)\end{array}$ & $\begin{array}{c}3 \\
(5.5)\end{array}$ & $\begin{array}{c}9 \\
(16.4)\end{array}$ & 0 & $\begin{array}{c}0 \\
(0.0)\end{array}$ \\
\hline $\begin{array}{l}\text { Supply } \\
\text { Chain } \\
\text { Manager/ } \\
\text { Procureme } \\
\text { nt Officer }\end{array}$ & $\begin{array}{c}5 \\
(16.7)\end{array}$ & $\begin{array}{c}4 \\
(13.3)\end{array}$ & $\begin{array}{c}3 \\
(10.0)\end{array}$ & 0 & $\begin{array}{c}0 \\
(0.0)\end{array}$ & $\begin{array}{c}15 \\
(50.0)\end{array}$ & 0 & $\begin{array}{c}3 \\
(10.0)\end{array}$ \\
\hline $\begin{array}{l}\text { Constructi } \\
\text { on } \\
\text { Materials } \\
\text { Vendor }\end{array}$ & 0 & 0 & $\begin{array}{c}1 \\
(20.0)\end{array}$ & 0 & $\begin{array}{c}1 \\
(20.0)\end{array}$ & $\begin{array}{c}3 \\
(60.0)\end{array}$ & 0 & 0 \\
\hline Total & $\begin{array}{c}217 \\
(28.60 \\
)\end{array}$ & $\begin{array}{c}84 \\
(11.1)\end{array}$ & $\begin{array}{c}157 \\
(20.9)\end{array}$ & $\begin{array}{c}37 \\
\mathbf{( 4 . 9 )}\end{array}$ & $\begin{array}{c}22 \\
(2.9)\end{array}$ & $\begin{array}{c}224 \\
(29.5)\end{array}$ & $\begin{array}{c}3 \\
(0.4)\end{array}$ & $\begin{array}{c}17 \\
(2.2)\end{array}$ \\
\hline
\end{tabular}

As it relates to the different e-Payment platforms used in the study area, the results are presented in Table 5 . It is evident in Table 5 that many (53.6\%) of those sampled in the survey used electronic fund transfer to make or receive payment for construction goods and services, while around 22\% indicated that they used credit cards to do this. Notably, these results appear to be in line with the previous study in the Nigerian building industry [6] but appear to contradict the earlier study which reported the none adoption of e-Payment systems in the Nigerian construction industry [17].

Furthermore, the e-Procurement technologies used in tracking the movement of materials/equipment and monitoring the progress of work in construction sites were also investigated in this study. From the results in Table 6, one can see that many of those sampled are not using these technologies, but among the users, the most commonly adopted technologies for this are web-based project management software packages, followed by web-based BIM and web-based multimedia technology.

Table 5: e-Payment Technologies

\begin{tabular}{|c|c|c|c|c|}
\hline \multirow{2}{*}{$\begin{array}{l}\text { Role in the } \\
\text { Construction } \\
\text { Industry }\end{array}$} & \multicolumn{4}{|c|}{ e-Payment Technologies } \\
\hline & None & $\begin{array}{l}\text { Electronic } \\
\text { Funds } \\
\text { Transfer } \\
\text { (EFT) }\end{array}$ & Credit Card & $\begin{array}{c}\text { SAP } \\
\text { System }\end{array}$ \\
\hline Architect & $\begin{array}{c}45 \\
(23.6) \\
\end{array}$ & $\begin{array}{c}84 \\
(44.0) \\
\end{array}$ & $\begin{array}{c}59 \\
(30.9) \\
\end{array}$ & $\begin{array}{c}3 \\
(1.6) \\
\end{array}$ \\
\hline Builder & $\begin{array}{c}10 \\
(14.5) \\
\end{array}$ & $\begin{array}{c}51 \\
(73.9) \\
\end{array}$ & $\begin{array}{c}7 \\
(10.2) \\
\end{array}$ & $\begin{array}{c}1 \\
(1.4)\end{array}$ \\
\hline Engineer & $\begin{array}{c}20 \\
(16.7) \\
\end{array}$ & $\begin{array}{c}72 \\
(60.0) \\
\end{array}$ & $\begin{array}{c}22 \\
(18.3)\end{array}$ & $\begin{array}{c}6 \\
(5.0)\end{array}$ \\
\hline Contractor & $\begin{array}{c}4 \\
(7.7)\end{array}$ & $\begin{array}{c}34 \\
(65.4)\end{array}$ & $\begin{array}{c}12 \\
(23.1)\end{array}$ & $\begin{array}{c}2 \\
(3.9)\end{array}$ \\
\hline $\begin{array}{l}\text { Construction/Pr } \\
\text { oject Manager }\end{array}$ & $\begin{array}{c}7 \\
(18.9)\end{array}$ & $\begin{array}{c}16 \\
(43.2)\end{array}$ & $\begin{array}{c}14 \\
(37.8)\end{array}$ & $\begin{array}{c}0 \\
(0.0)\end{array}$ \\
\hline $\begin{array}{l}\text { Quantity } \\
\text { Surveyor }\end{array}$ & $\begin{array}{c}59 \\
(29.5) \\
\end{array}$ & $\begin{array}{c}101 \\
(50.5)\end{array}$ & $\begin{array}{c}36 \\
(18.0) \\
\end{array}$ & $\begin{array}{c}4 \\
(2.0)\end{array}$ \\
\hline $\begin{array}{l}\text { Estate/ Facilities } \\
\text { Manager }\end{array}$ & $\begin{array}{c}20 \\
(36.4)\end{array}$ & $\begin{array}{c}24 \\
(43.6) \\
\end{array}$ & $\begin{array}{c}11 \\
(20.0)\end{array}$ & $\begin{array}{c}0 \\
(0.0)\end{array}$ \\
\hline
\end{tabular}

Blue Eyes Intelligence Engineering \& Sciences Publication

(C) Copyright: All rights reserved. 


\begin{tabular}{|l|c|c|c|c|}
\hline $\begin{array}{l}\text { Supply Chain } \\
\text { Manager/ } \\
\text { Procurement } \\
\text { Officer }\end{array}$ & $\begin{array}{c}2 \\
(6.7)\end{array}$ & $\begin{array}{c}21 \\
(70.0)\end{array}$ & $\begin{array}{c}5 \\
(16.7)\end{array}$ & $\begin{array}{c}2 \\
(6.7)\end{array}$ \\
\hline $\begin{array}{l}\text { Construction } \\
\text { Materials/Equip } \\
\text { ment Vendor }\end{array}$ & 0 & $\begin{array}{c}4 \\
(80.0)\end{array}$ & 0 & $\begin{array}{c}1 \\
(20.0)\end{array}$ \\
\hline Total & $\begin{array}{c}\mathbf{1 6 7} \\
(\mathbf{2 2 . 0})\end{array}$ & $\begin{array}{c}\mathbf{4 0 7} \\
\mathbf{( 5 3 . 6 )}\end{array}$ & $\mathbf{1 6 6}$ & $\mathbf{1 9}$ \\
\hline
\end{tabular}

Table 6: e-Tracking Technologies

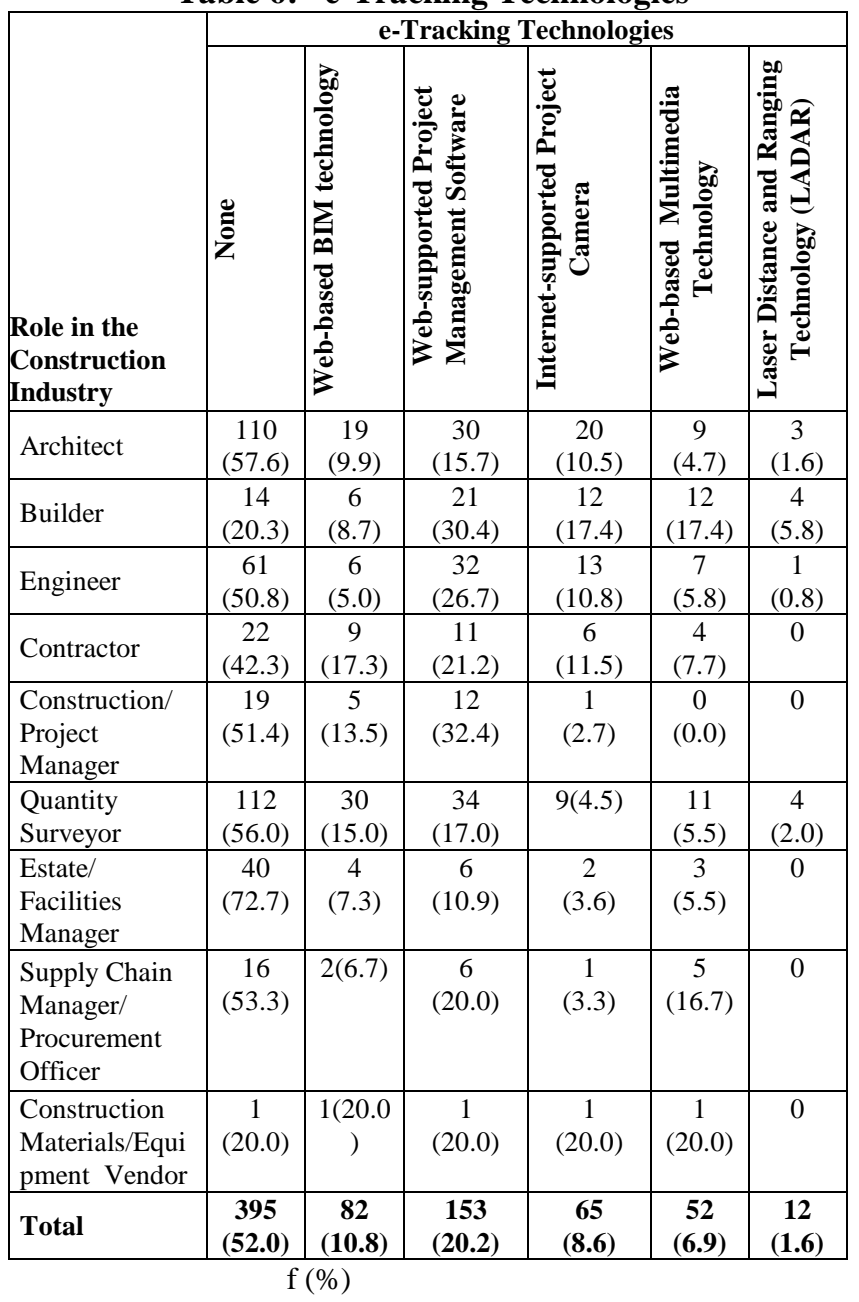

This result in Table 6 suggests that many of the stakeholders in the construction industry in Nigeria who participated in the survey are yet to take advantage of the Internet technology in the management of construction contracts.

Table 7 shows the results of the specific e-Procurement technologies used to disseminate or receive information on tender opportunities. From the results in Table7 it is evident that the most commonly used e-Notification/Announcing/Informing technology is e-mail, followed by web portal and instant messaging, respectively. These results are consistent with that in a previous study in South Africa by previous authors which reported predominant use of email as a basic e-Notification tool amongst construction people in that country [2].

Table 8 shows the results of the e-Tendering technologies used by those sampled in the survey. From the results (Table 8), it is evident that e-Mail is the most commonly used e-Tendering technology. This followed by web portal and dropbox, respectively. Although this result appears to be consistent with that by the study in Nigeria [11] and that in
South Africa [28] on the use of e-mail and web portals as e-Tendering technologies, it contracts the finding in Malaysia which reported the use of more advanced e-Tendering systems like Arriba, Oracle and others in the Malaysian construction industry [8].

Regarding the specific e-Procurement technologies used in the exchange of construction project information and data not related to disseminating or receiving information on the availability of tender opportunities. From the results (Table 9) it is also evident that most of the stakeholders in the Nigerian construction industry who took part in the survey use e-mail to exchange project information such as project briefs and specifications, bill of quantities, drawings and others. This is followed by web portal and the least is Microsoft SharePoint. Again, this is similar to findings of previous studies in the South African construction industry [2] and that in the Nigerian building industry [12], both of which reported massive use of these technologies in the transmission of vital project data and information at both intra and inter firms or organization levels.

From the foregoing results, it evident that in the Nigerian construction industry, the main e-Procurement systems used are Notification/Informing/Announcing, e-Exchange, e-Tendering, and e-Awarding systems, e-Ordering and e-Payment systems. This seems that suggest that stakeholders in the construction industry in Nigeria are beginning to take advantage of the Internet in executing their procurement business, which of course, is the global best practice designed to circumvent some of the challenges associated with the paper-based and manual method of conducting construction procurement activities. It was however observed that the use of e-Tracking was relatively low.

From the array of e-Procurement technologies identified, our survey data reveal that apart from the use of electronic fund transfer identified as the most popular e-Payment system in use, e-Mails, websites and web portals are the most common technologies for e-Notification/Informing/Announcing, e-Exchange, e-Tendering, and e-Awarding and e-Ordering. Notably, e-Mails, websites and web portals are the simplest tools and applications for e-Commerce in the different industrial sectors and they facilitate seamless exchange of information but have limited capabilities when it comes to procurement activities that require significant level of coordination of inputs, collaborative engagement and integration of activities, human beings and processes involved in the procurement of construction projects. This suggests that significant barriers exist in the use of advance e-Procurement technologies by stakeholders in the Nigerian construction industry. 
Table 7: e-Notification Technologies

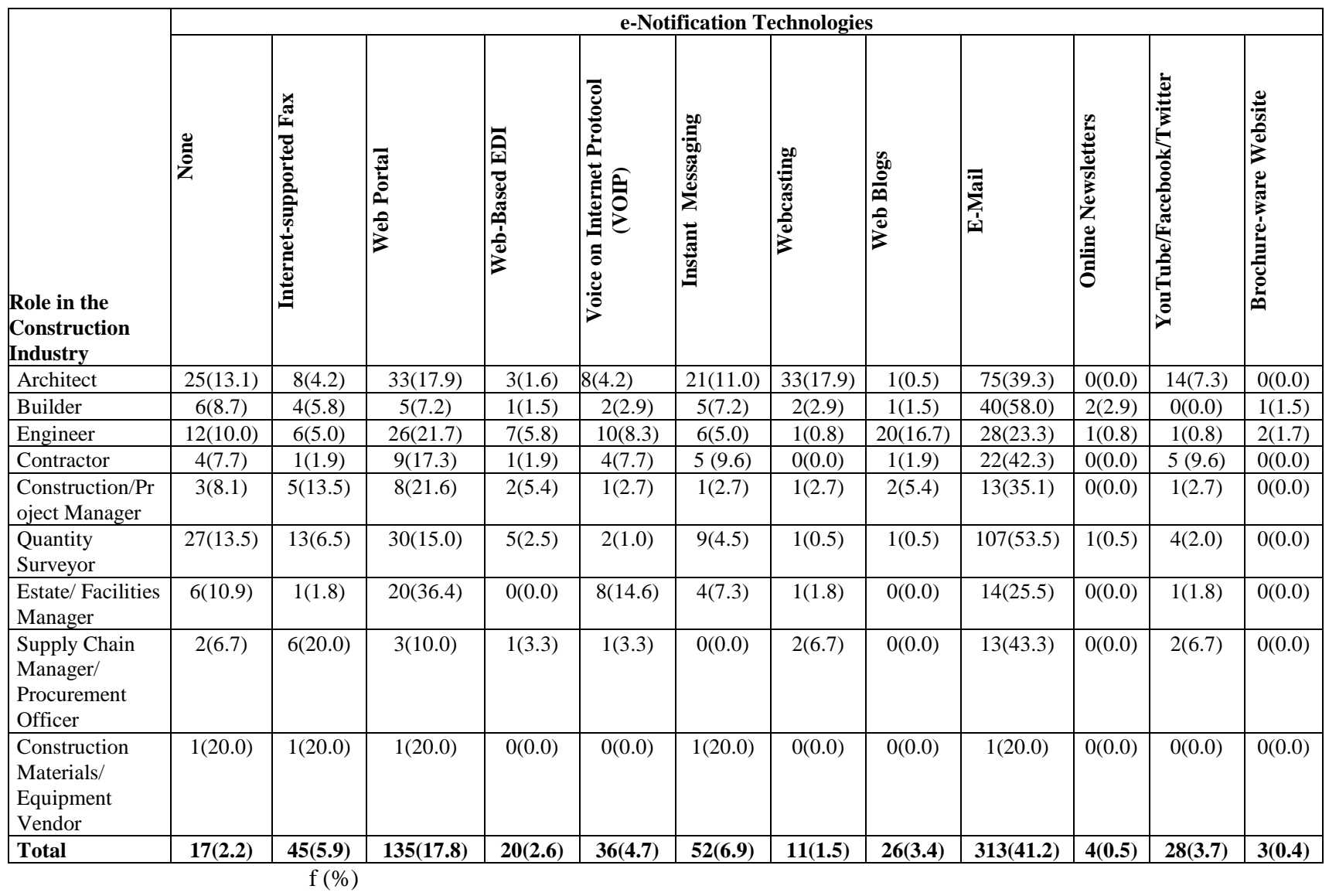

Table 8: e-Tendering Technologies

\begin{tabular}{|c|c|c|c|c|c|c|c|c|c|c|c|}
\hline \multirow[b]{2}{*}{$\begin{array}{l}\text { Role in the } \\
\text { Construction } \\
\text { Industry }\end{array}$} & \multicolumn{11}{|c|}{ e-Tendering Technologies } \\
\hline & 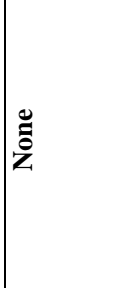 & 胥 & 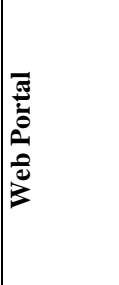 & 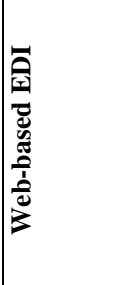 & 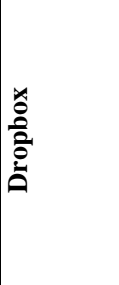 & 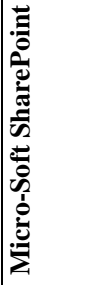 & : & 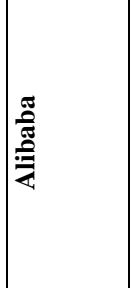 & పัँّ & 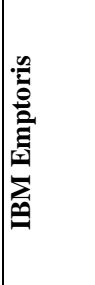 & 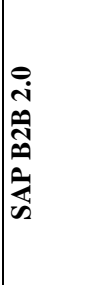 \\
\hline Architect & $62(32.5)$ & $94(49.2)$ & $16(8.4)$ & $0(0.0)$ & $11(5.8)$ & $2(1.1)$ & $0(0.0)$ & $1(0.5)$ & $1(0.5)$ & $1(0.5)$ & $3(1.6)$ \\
\hline Builder & 11(15.9) & $44(63.8)$ & $5(7.2)$ & $4(5.8)$ & $2(2.9)$ & $0(0.0)$ & $0(0.0)$ & $1(1.4)$ & $22(2.9)$ & $0(0.0)$ & $0(0.0)$ \\
\hline Engineer & $30(25.0)$ & $64(53.3)$ & 15(12.5) & $2(1.7)$ & $3(2.5)$ & $33(2.5)$ & $0(0.0)$ & $0(0.0)$ & $1(0.8)$ & $0(0.0)$ & $2(1.7)$ \\
\hline Contractor & $7(13.5)$ & $33(63.5)$ & $9(24.3)$ & $0(0.0)$ & 2(3.9) & $0(0.0)$ & $1(1.9)$ & $0(0.0)$ & $0(0.0)$ & $0(0.0)$ & $0(0.0)$ \\
\hline $\begin{array}{l}\text { Construction/Project } \\
\text { Manager }\end{array}$ & $9(24.3)$ & $20(54.1)$ & $6(16.2)$ & $0(0.0)$ & $1(2.7)$ & $0(0.0)$ & $1(2.7)$ & $0(0.0)$ & $0(0.0)$ & $0(0.0)$ & $0(0.0)$ \\
\hline Quantity Surveyor & $79(39.5)$ & $91(45.5)$ & $12(6.0)$ & $5(2.5)$ & $6(3.0)$ & $2(1.0)$ & $1(0.5)$ & $2(1.0)$ & $1(0.5)$ & $1(0.5)$ & $0(0.0)$ \\
\hline $\begin{array}{l}\text { Estate/ Facilities } \\
\text { Manager }\end{array}$ & 17(30.9) & $27(49.1)$ & $8(14.6)$ & $2(3.6)$ & $1(1.8)$ & $0(0.0)$ & $0(0.0)$ & $0(0.0)$ & $0(0.0)$ & $0(0.0)$ & $0(0.0)$ \\
\hline $\begin{array}{l}\text { Supply Chain Manager/ } \\
\text { Procurement Officer }\end{array}$ & $6(20.0)$ & $18(60.0)$ & $2(6.7)$ & $0(0.0)$ & $1(3.3)$ & $3(10.0)$ & $0(0.0)$ & $0(0.0)$ & $0(0.0)$ & $0(0.0)$ & $0(0.0)$ \\
\hline $\begin{array}{l}\text { Construction } \\
\text { Materials/Equipment } \\
\text { Vendor }\end{array}$ & $1(20.0)$ & $3(60.0)$ & $0(0.0)$ & $0(0.0)$ & $0(0.0)$ & $0(0.0)$ & $1(20.0)$ & $0(0.0)$ & $0(0.0)$ & $0(0.0)$ & $0(0.0)$ \\
\hline Total & 222(29.3) & 394(51.9) & $73(9.6)$ & $13(1.7)$ & $27(3.6)$ & $10(1.3)$ & $4(0.5)$ & $4(0.5)$ & $5(0.7)$ & $2(0.3)$ & $5(0.7)$ \\
\hline
\end{tabular}


Table 9: e-Exchange Technologies

\begin{tabular}{|c|c|c|c|c|c|c|c|c|}
\hline & \multicolumn{8}{|c|}{ e- Exchange technologies } \\
\hline & 竞 & 胥 & 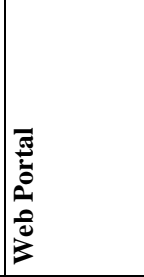 & 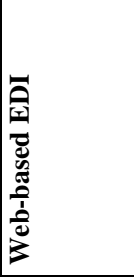 & $\begin{array}{l}x \\
0 \\
0 \\
0 \\
0 \\
0 \\
0\end{array}$ & 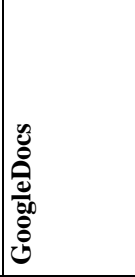 & 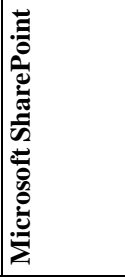 & 总 \\
\hline Architect & $18(9.4)$ & 114(59.7) & $29(15.2)$ & $2(1.1)$ & $11(5.8)$ & $7(3.7)$ & $0(0.0)$ & $10(5.2)$ \\
\hline Builder & $0(0.0)$ & $51(73.9)$ & $5(7.3)$ & $1(1.5)$ & $2(2.9)$ & $22(2.9)$ & $1(1.5)$ & $7(10.1)$ \\
\hline Engineer & $8(6.7)$ & $80(66.7)$ & $12(10.0)$ & $7(5.8)$ & $5(4.2)$ & $3(2.5)$ & $2(1.7)$ & $3(2.5)$ \\
\hline Contractor & $2(3.8)$ & $32(61.5)$ & $11(21.2)$ & $2(3.8)$ & $3(5.8)$ & $0(0.0)$ & $0(0.0)$ & $2(3.8)$ \\
\hline Construction/Project Manager & $6(16.2)$ & $21(56.8)$ & $8(21.6)$ & $0(0.0)$ & $1(2.7)$ & $0(0.0)$ & $0(0.0)$ & $1(2.7)$ \\
\hline Quantity Surveyor & $32(16.0)$ & $121(60.5)$ & $12(6.0)$ & $9(4.5)$ & $6(3.0)$ & $4(2.0)$ & $3(1.5)$ & $13(6.5)$ \\
\hline Estate/ Facilities Manager & $7(12.7)$ & $33(60.0)$ & $11(20.0)$ & $1(1.8)$ & $1(1.8)$ & $0(0.0)$ & $0(0.0)$ & $2(3.7)$ \\
\hline $\begin{array}{l}\text { Supply Chain Manager/ } \\
\text { Procurement Officer }\end{array}$ & $2(6.7)$ & $16(53.3)$ & 1(3.3) & $2(6.7)$ & $5(16.7)$ & $0(0.0)$ & $0(0.0)$ & $4(13.3)$ \\
\hline $\begin{array}{l}\text { Construction } \\
\text { Materials/Equipment Vendor }\end{array}$ & $0(0.0)$ & $2(40.0)$ & $0(0.0)$ & $0(0.0)$ & $1(20.0)$ & $0(0.0)$ & $0(0.0)$ & $2(40.0)$ \\
\hline Total & 75(9.9) & $470(61.9)$ & 89(11.7) & $24(3.2)$ & $35(4.6)$ & 16(2.1) & $6(0.8)$ & 44(5.8) \\
\hline
\end{tabular}

$\mathbf{f}(\%)$

\section{CONCLUSIONS}

This study investigated the different types of e-Procurement systems and technologies used by stakeholders in the Nigerian construction environment. Based on the results of analysis of the data from 759 users of e-Procurement in the study area, two key conclusions are made. The first conclusion is that there is evidence of a significant number of users of e-Notification/Informing/Announcing, e-Exchange, e-Tendering, e-Award systems, e-Order and e-Payment systems, while the use of e-Tracking systems is not very common amongst construction industry stakeholders in Nigeria. The second conclusion is that e-Mail, websites and electronic funds transfer are the predominant e-Procurement technologies used by people in the Nigerian construction environment to support the execution of construction procurement activities. The findings of this study suggest that the aforementioned e-Procurement systems and technologies are the ones currently known and used in the Nigerian construction environment. Arguably, the emergence of e-Mail as the most commonly used e-Procurement technology amongst participants in this survey is an indication that the Nigerian construction industry still relies on the simplest form of Internet services to support the execution of construction procurement activities. This situation will most likely limit the extent to which the industry can derive optimal benefits from the use of e-Procurement as e-Mails do not have the capacity to effectively and efficiently integrate people, process and activities involved in the procurement of construction projects. In view of this, there is a need for people in the industry to invest more in other e-Procurement systems and technologies that have the capacity to perform multiple functions such as information dissemination, coordination, integration and collaboration in construction procurement process. In the same vein, developers and vendors of e-Procurement systems and technologies need to create more awareness on the potential benefits in the use of advance e-Procurement systems to encourage and promote their adoption, thereby leading to a reduction in over dependence on e-Mails and other simple e-Procurement technologies and tools in Nigeria.

\section{ACKNOWLEDGMENTS}

The authors would like to appreciate Covenant University Center for Research Innovation Discovery and Development (CUCRID) for providing the grant that made this research possible. The contributions of all the research assistants involved in the data collection process and participations in the research are also appreciated.

\section{REFERENCES}

1. Waston, A. S. (2011) Digital Buildings- Challenges and Prospects. Advanced Engineering Informatics. Vol. 25(4), P.- 573-581

2. Ibem, E.O and Laryea, S. (2015). E-Procurement use in the South African construction industry. Journal of Information Technology in Construction Vol.20. P.- 364-384

3. Ruikar, K., Anumba, C.J. and Carrillo, P.M. (2006). VERDICT-An e-Readiness Assessment Application for Construction Companies. Automation in Construction, Vol.15. P-98-110.

4. Kaliannan, M \& Awang, H. (2009). ICT to Enhance Administrative Performance: A case study from Malaysia. International Journal of project delivery and Management, Vol. 3 (5), P.-.78-84

5. Vitkauskaite, E. \& Gatautis, R. (2008). E-Procurement Perspectives in Construction Sector. Journal of Civil Engineering and Management, 14(4), pp. 287-294.

6. Aduwo, E. B., Ibem, E. O., Ayo-Vaughan, E. A., Uwakonye, O., and Owolabi, J. D. (2017). E-procurement use in the Nigerian building industry. International Journal of Electronic Commerce Studies, 8 (2), pp. 219-254

7. Neupane, A., Soar, J., \& Vaidya, K. (2012). Evaluating the Anti-Corruption Capabilities of Public e-Procurement in a Developing Country. The Electronic Journal of Information Systems in Developing Countries 5(1), pp. 1-17

8. Zakaria, R. Kwong, L.Z., Nilashi, M., Abd. Majid, M.Z., Ibrahim, O. \& Zin, R. H. (2014). Ethical Behaviors in e-Tendering Process for Construction project in Malaysia. Journal of Theoretical and Applied Information Technology, 70(1), pp.210-225

9. Eadie, R., Perera, S., Heaney, G. and Carlisle, J. (2007). Drivers and Barriers to Public Sector e-procurement within Northern Ireland's Construction Industry. Journal of Information Technology in Construction (ITcon), 12(2007), 103-120.

10. Eadie, R., Perera, S. and Heaney, G. (2011). Analysis of 
the use of E-Procurement in the Public and Private Sectors of the UK construction Industry. Journal of Information Technology in Construction(ITcon), 16(2011), 669-686

11. Hashim, N., Said I., and Idris (2014). e-Procurement Implementation in Malaysian Construction Industry. Aust. J. Basic \& Appl. Sci. Vol 8(6). P.-231-238

12. Aduwo, E. B.; Ibem, E.O; Tunji-Olayeni, P., Uwakonye; O. U. \& Ayo-Vaughan, E. K (2016) Barriers to the Uptake of e-Procurement in the Nigerian Building Industry. International Journal of Applied Theoretical and Applied Information Technology. Vol. 89(1), P. 133-14

13. Nawi, M. N. M., Deraman, R., Bamgbade, J. A., Zulhumadi, F., Riazi, S.R. M., (2017). E-Procurement in Malaysian Construction Industry: Benefits and Challenges in Implementation. International Journal of Supply Chain Management, Vol. 6(1), P.- 209-213

14. Zunk, B. M., Marchner, M., Uitz, I., Lerch, C., \& Schiele, H. (2014). The Role of E-Procurement in the Austrian Construction Industry: Adoption Rate, Benefits and Barriers. International of Industrial Engineering and Management, Vol.5(2), P.-13-21.

15. Isikdag, U. (2019). An Evaluation of Barriers to e-Procurement in Turkish Construction Industry. International Journal of Innovative Technology and Exploring Engineering,Vol. 8(4), P.-252-259

16. Afolabi, A., Ibem, E.O; Aduwo, E.B.; Tunji-Olayeni, P.F. \& Oluwunmi, A. A. (2019). Critical Success Factors (CSFs) for e-Procurement Adoption in the Nigerian Construction Industry. Buildings, Vol. 47 (9), P.- 2-18.

17. Oyediran O. S. and Akintola A. A. (2011). A Survey of the State of the art of e-Tendering in Nigeria. Journal of Information Technology in Construction, Vol. 32, P.-1-20.

18. Ibem, E.O., Aduwo, E.B., Tunji-Olayeni, P., Uwakonye, O.U. \& Ayo-Vaughan, E. K. (2016). Factors Affecting E-Procurement Adoption in the Nigerian Building Industry, Construction Economics and Building, Vol. 16(4), P.-54-67

19. Kajewski, S. and Weippert, A. (2004). E-Tendering: Benefits, Challenges and Recommendations for Practice. In Proceedings CRCCI International Conference: Clients Driving Innovations, Surfer Paradise, Australia

20. Rankin J., Chen Y., and Christian A. (2006). E-procurement in the Atlantic Canadian AEC Industry, Journal of Information Technology in Construction, Vol. 11. P.-75-87

21. Teo, T.S.H, Lin, S. \& Lai, K. (2010). Adopters and non-adopters of e-Procurement in Singapore: An Empirical Study. Omega, 37, P.972-987.

22. Heddad, S.M.A. (2013). E-Tendering System Automated Manual System of SOC. Journal of Computing \& Organizational Dynamics, Vol. 1(1), P.- 1-7

23. Gunasekaran, A. and Ngai, E.W.T. (2008). Adoption of e-Procurement in Hong Kong: An empirical research, International Journal of Production Economics, Vol.113(1), P.159-175

24. Laryea, S. and Ibem, E. O. (2014). Patterns of Technological Innovation in the use of e- Procurement in Construction. Journal of Information Technology in Construction, Vol. 19, P.- 104-125

25. Issa, R.R.A., Flood, I. and Caglasin, G. (2003). Survey of E-Business Implementation in the US Construction Industry. Journal of Information Technology in Construction, Vol. 8, P.-15-28

26. Zuo, P. X. W and Seo, Y. (2006). Effective Applications of E-Commerce Technologies in Construction Supply Chain: Current Practice and Future Improvement. Journal of Information Technology in Construction, Vol.11. P.- 127-147.

27. Cochran, W. G. Sampling Technique. 2nd Edition, John Wiley and Sons Inc., New York, 1963

28. Ibem, E.O. \& Laryea, S. (2017) E-tendering in the South African construction industry, International Journal of Construction Management, Vol.17(4), P.- 310-328

\section{AUTHORS PROFILE}

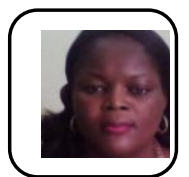

Egidario B. Aduwo is a senior lecturer at Covenant University, Ota, Nigeria, in the Department of Architecture. She holds a PhD in Architecture from the same university. She an architect and member Nigerian Institute of Architects (NIA)Her research interests are in the areas of housing transformation, interior and landscape architecture and sustainable and affordable housing procurement practices. She has published several research articles and also supervised both undergraduate and postgraduate students in architecture.
Eziyi O. Ibem is a Professor of Architecture. He holds a PhD degree in Architecture of Covenant University, Ota, Nigeria. He is a registered architect by the Architects Registration Council of Nigeria(ARCON) and member Nigeria Institute of Architects (NIA). He is currently teaching and doing research at the Department of Architecture, University of Nigeria, Enugu Campus and serving as a Visiting Professor at Covenant University, Ota, Nigeria and University of Johannesburg, South Africa. His research work is in the areas of sustainable human settlements, post occupancy evaluation, environment-behaviour and application of digital tools in design and construction.

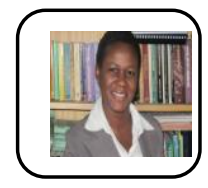

Adedamola O. Oluwnmi is a Senior Lecturer at Covenant University, Ota, Nigeria, in the Department of Estate Management. She holds a $\mathrm{PhD}$ in Estate Management from the same university and the areas of her research interests include post occupancy evaluation of academic facilities and ICT in facilities management

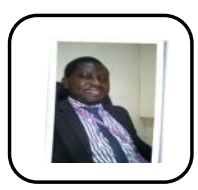

Adedeji O. Afolabi is a Lecturer at Covenant University, Ota, Nigeria, in the Department of Building Technology. He holds a $\mathrm{PhD}$ from the same university and has research interest in the areas of ICT in construction, sustainable and green construction practices, and construction education. He has published over 60 research articles in globally recognized outlets and his works have received several hundreds of citations across the world. 